\title{
Academic Cooperation in the Humanities and Social Sciences: A Post-COVID Future
}

\author{
Andreas Mehler and Francis B. Nyamnjoh
}

\section{Introduction}

Academic cooperation within Africa (between African universities and research centres) on the one hand, and outside the continent on the other, needs to be rethought in the light of past and current experiences and in the interest of greater equity in collaborative research and scholarship. The landscapes of such institutions have changed dramatically over time, and are likely to change further with the imperatives of a post-COvID-19 reconfiguration, which will have implications for knowledge production, distribution and consumption.

In this short contribution, while we cannot trace all trajectories back to the end of the colonial era, it is obvious that some research institutions of the early days of independence have survived the last fifty or so years rather well - places like Makerere, Legon or Dakar come to mind. However, many new universities were created in the meantime, some of them backed by private investors. More importantly, old and new institutions work in a different environment today. Arguably, though connections to colonial metropoles and some viable inter-African ones endure, most probably, given the ever-increasing circles of interconnections and interdependences in a globalized world, Africa's global connections will create additional dynamics in the foreseeable future. Although the languages and cultures of former colonizing powers retain their influences, local practices have long challenged the dominance of colonial models of thinking and, more recently, the repercussions of global power shifts (consider the roles of the USA or, especially in the new millennium, China) are being played out.

Here we wish to suggest some avenues along which academic cooperation might lead in the forthcoming decade. Albeit with a strong focus on the social sciences and humanities, we draw on our combined experiences as scholars of Africa who have researched, taught in institutions and participated in various collaborative initiatives (local, regional and international) that we consider instructive for reimagining the future of academic cooperation on knowledge production in, on and around Africa. Our academic conversations date back to the early 199os in Yaoundé, when we were first introduced to each other through

(C) ANDREAS MEHLER AND FRANCIS B. NYAMNJOH, 2022｜ DOI:10.1163/9789004471641_032 
the auspices of the Friedrich Ebert Foundation, as scholars with a common interest in using research to contribute to the mobilization and strengthening of civil society in Cameroon. Today, we find ourselves involved with the Merian Institute for Advanced Studies in Africa (MIASA) at the University of Ghana. ${ }^{1}$

\section{The Future of Academic Knowledge Production}

Ethical, epistemological and material dilemmas are associated with the ongoing imbalance in knowledge production worldwide, and they particularly haunt area studies (Hoffmann and Mehler 2011). Attempts to change this situation, however, have been witnessed on numerous occasions. For instance, a high proportion of panels at the preceding European Conference on African Studies (ECAS) in Edinburgh in 2019 had a 'decolonial' perspective. However, many contributions lacked a strategic perspective or answers to the question of how to overcome the current distorting practices of Northern theory-building, research agendas and publication outlets, while there are already constructive proposals to decolonize the academy at hand (for example Nyamnjoh 2019, 2020). Many obstacles also exist on the continent itself.

The following challenges persist:

- The dominance of non-African writers on African issues in academic journals is striking and could be a major reason why theories and concepts, questions and proposed solutions seem to come predominantly from outside the continent. Underrepresentation is also an issue on the level of editors or academic boards. Many established journals claim to be trying to be more inclusive, but believe that the problem resides elsewhere: also, few African thinkers are in a position to invest in such - mostly pro bono - roles when they are insufficiently paid by their home institutions.

- Moreover, the global asymmetry in knowledge production frequently makes it impossible for African scholars to read what African colleagues have produced since they are unable to access their work directly. The prevailing asymmetry between the sources of knowledge production has a direct bearing on the nature and practice of both the humanities and the social sciences.

1 MIASA attracts senior and junior fellows to work on the broad theme of sustainable governance. German partners are the universities of Freiburg and Frankfurt, the German Historical Institute in Paris and the German Institute of Global and Area Studies (GIGA) in Hamburg. See https://www.ug.edu.gh/mias-africa/. 
- Material investment in Africa's research environment is altogether minimal. Research is rarely among the priorities of African governments or private investors. This has led to a continuation or exacerbation of an outside dependence on extra-continental initiatives. While those are frequently benevolent, the risk of perpetuating relations of dominance is obvious.

- While it is fully understandable that many African thinkers want to invest in basic research, it is hardly imaginable that African governments, or other actors, will provide more material input without at least a promise of alternative solutions to pressing societal issues. The gap between academia, policy circles and broader society is not necessarily narrower in Africa than elsewhere in the world.

- Bridging the divide between the widely diverging intellectual traditions that have their origins in anglophone, francophone and other linguistic backgrounds is necessary, but not easy to achieve.

- Closing the gap between a growing cohort of aspiring younger African scholars and the small elite of a global African intelligentsia frequently residing outside the continent is another challenge.

- Female African researchers regularly encounter structural obstacles to their academic advancement. They are usually underrepresented in academic leadership positions, have additional work-life balance challenges when fulfilling 'traditional' female roles and often do not get the same visibility as male colleagues. Being African and being female are intersecting features producing multiple forms of exclusion.

A new challenge has appeared just recently - the Covid-19 pandemic, which has already affected academic cooperation within and between continents. As in any other global crisis of the twenty-first century - take the upsurge of terrorism and counter-terrorism in the context of $9 / 11$, or the global financial crisis from 2007 onwards - we witness a compression of time and space. As the virus expands quickly, so too do competing exercises of sense-making, frantic searches for solutions, or strategies of containment. The public attention may have been elsewhere, but effects are tangible for any form of encounter between scholars. Academic conferences were called off; institutes for advanced studies had to postpone fellowships. As a stop-gap measure, academics have joined the bandwagon of digital alternatives that have usually served as complements of in-person face-to-face interactions. Once again, hardships and risks are unequally distributed among scholars operating in differently equipped institutions. Whether the virus will have a levelling effect - when similar obstacles to academic hyper-mobility hit all quarters in a similar fashion - is far from clear in general and in the realm of academic cooperation in particular; it more likely sheds light again on the privileges of the North. 
However, if ever the denomination as 'crisis' should have a meaning, it could also bring positive effects. But it is now that we have to act. In fact, we witness that the coincidence of COVID-19 with the Black Lives Matter discussions in spring 2020 has raised consciousness levels about privileges, open or covert exclusion linked to structural racism not least within universities and the academic world more generally. How could the dismal status quo be overcome? By working on different levels - spirit, governance and technology. Let us only sketch some of the elements on those levels:

Spirit: Solidarity or much better Ubuntu, the comfort of being part of a community that is much larger than one's immediate surroundings should help us to form a much more solid basis of cooperation - within academia and beyond. In particular, we should incite instead of limit (reciprocal) curiosity on aspects of social life that look only at first sight unrelated to big global issues. Furthermore, humility, openness and relatedness are more rewarding than sterile competition.

Governance: Within academic institutions, but also within networks we can observe a higher sensitivity towards only partly binding rules - potentially because the opportunities (to get recruited or to attend meetings) are shrinking. Never before was there such attention paid to the composition of academic boards, speakers at panels, or authors within edited volumes. This might be the right moment to set standards that aim at inclusion and complementarity.

Technology: Virtual gatherings, though critically lacking the intimacy of physical encounters and the productive chats in coffee breaks after a panel session, have lowered the bar of participating in academic exchanges. We see more junior and female participants at academic gatherings; old white men do not dare as much as they did in the past to monopolize the debate in teleconferences. However, IT equipment and signal strength is an issue still haunting scholars operating in and from Africa. This is one front that can and should be tackled quickly.

This complex set of issues was never left fully unaddressed, which means that we have a basis for operation: one such example is the Council for the Development of Social Science Research in Africa (CODESRIA), which was founded in 1973 to provide for and promote greater equality in knowledge production on and around Africa by ensuring more recognition and presentation for knowledge produced by Africans, and especially from African perspectives. It has achieved significant milestones, but much remains to be done. Other institutions have been created with similar mandates, just as universities have embarked on transformative endeavours towards mitigating these challenges.

It is desirable that good ideas are put into a joint strategic framework and speak to each other. This, again is likely to provoke original new thinking and, ideally, innovative research collaborations. 


\section{3}

\section{Convivial Scholarship}

Combining efforts of like-minded institutions will contribute to cumulative change in academic development.

We recommend research collaboration grounded in a recognition of incompleteness as the normal order of things, and which draws on convivial scholarship (Nyamnjoh 2017). Dimensions of incompleteness include relatedness, openness, enrichment, humility and action. Academic cooperation with a framework of incompleteness is predisposed to and predisposes myriad interconnections, embeddedness and inextricable entanglements. It invites openness and reaching out across borders, to explore alternatives, and to build bridges as a mode of inclusionary existence. Recognizing incompleteness opens the door to connectivity and interdependence, active participation, mutual fulfilment and enrichment. It compels us as researchers and scholars of Africa to broaden our perspectives, embrace the unknown and the unknowable, and be open-ended, open-minded and flexible in our identity claims and disclaimers.

We argue that an approach to research collaboration informed by a recognition of incompleteness as the normal order of being would foreground conviviality in a manner that allows for Africans and Europeans (or any other non-Africans) involved in collaborative research to be more open to possible enrichment with creative, cultural, social and intellectual African potentials derailed or caricatured by the orgy of coercive colonial violence and impulse to monopolize humanity and the world's resources.

In our future collaborative research endeavours pertaining to Africa, it would help to bear in mind the following question. If Africa is part of a nimblefooted world where things and people are permanently in circulation even in confinement, how do we provide for collaborative research that does justice to the reality of constant mobility of people and things African, European and otherwise?

A truly convivial scholarship is one that does not seek a priori to define and confine Africans into particular territories or geographies, particular racial and ethnic categories, particular classes, genders, religions or whatever other identity marker. Convivial scholarship confronts and humbles the challenge of over-prescription and over-standardization. It is critical and evidence based; it challenges problematic labels, especially those that seek unduly to oversimplify the social realities of the people and places it seeks to understand and explain. Convivial scholarship recognizes the deep power of collective imagination and the importance of interconnections and nuanced complexities. It is a scholarship that sees the local in the global and the global 
in the local by bringing them into informed conversations, conscious of the hierarchies and power relations at play at both the micro and macro levels of being and becoming. It is a critical scholarship of recognition and reconciliation, one that has no permanent friends, enemies or alliances beyond the rigorous and committed quest for knowledge in its complexity and nuance, and using the results of systematic enquiry to challenge inequalities, foster justice and inspire popular visions, versions and aspirations for the good life. Convivial scholarship does not impose what it means to be human, just as it should not prescribe a single version of the good life in a world peopled by infinite possibilities. Rather, it encourages localized conversations of a truly global nature on competing and complementary processes of social cultivation through practice, performance and experience, without pre-empting or foreclosing particular units of analysis in a world in which the messiness of encounters and relationships frowns on binaries, dichotomies and dualisms. With convivial scholarship, there are no final answers, only permanent questions and questioning.

\section{Future Forms of Cooperation}

One obvious element of a future agenda is to make scholarly voices from the continent audible on a global scale - and not only on issues pertaining to Africa. In the future it will be essential to highlight vanguard knowledge production by African scholars rooted in innovative thinking, that is confronting 'old' with 'new' ideas. Some dominant theories in the social sciences and the humanities have not fully survived their empirical test in Africa, but indeed die hard and have yet to be replaced by more appropriate theories. Where could such new ideas be developed?

Some leading social scientists see the future in the rear-view mirror, pointing to the merits of revisiting the past for inspiration, with an explicit or assumed nostalgia for what intellectual life was in places like Dar es Salaam in the 196os, that is a place of intense encounter of some of the brightest thinkers from Africa at that time, all inspired by a pan-Africanist perspective of Africa (Ndlovu-Gatsheni 2013). It is highly debatable whether this could be more than a utopia and also whether the all-male composition of the revered group of thinkers is today still an attractive model to be embraced unquestioningly.

But spaces to think freely from daily pressures are as precious as they always were and a number of initiatives stand out. MIASA is one such initiative that aims at highlighting ideas and innovative approaches by some of the brightest intellectuals of the continent. MIASA wants to help its fellows to develop new and grounded approaches by confronting theoretical thinking with practical 
needs, without, however, prescribing any directions. There is a growing need for places of intense exchange between African and non-African thinkers, striving for maximal symmetry.

A humble new initiative is the Africa Centre for Transregional Research at Freiburg University. ${ }^{2}$ The particular focus of the centre is to attract African scholars interested in reciprocal research, not necessarily in African studies, but phenomena at first sight situated in Europe (for example migration policies of the European Union, industrial food production or the restitution debate raging in the museum world) are explicable only when taking local actor constellations into account, but with clear relations to the African continent, all along the way from needs perceptions up to political repercussions. The call for transregional research implies African scholars doing research in Europe/on Europeans (and hopefully with Europeans). As Dzodzi Tsikata the immediate past president of the executive committee of CODESRIA, director of the Institute of African Studies at the University of Ghana and member of MIASA's executive council has put it: this is about "normalising Africans as scientists and knowers who may come from elsewhere." ${ }^{3}$

\section{Acknowledgement}

Our joint thinking owes a lot to the Merian Institute for Advanced Studies in Africa (MIASA) where we are members of the Academic Advisory Board and the Executive Council, respectively. MIASA as a project is mostly funded by the (German) Federal Ministry of Education and Research, but relies on substantial investment and equipment offered by the University of Ghana.

\section{References}

Hoffmann, B. and A. Mehler. 2011. "Area studies". In International encyclopedia of political science, edited by B. Badie, D. Berg-Schlosser and L. Morlino, 89. Newbury: Sage. Ndlovu-Gatsheni, S. J. 2013. Coloniality of power in postcolonial Africa. Myths of decolonization. Dakar: Codesria.

Nyamnjoh, F. B. 2017. "Incompleteness and conviviality: A reflection on international research collaboration from an African perspective." In African virtues in the pursuit of conviviality: Exploring local solutions in light of global prescriptions, edited by Y. Gebre, I. Ohta and M. Matsuda, 339-378. Bamenda: Langaa.

2 https://www.act.uni-freiburg.de/en?set_language=en.

3 https://www.arnold-bergstraesser.de/en/freiburg-africa-talks. 
Nyamnjoh, F. B. 2019. "Decolonizing the University in Africa”. In Oxford Research Encyclopedia of Politics, edited by W. R. Thompson et al., online. Oxford: Oxford University Press. DOI: 10.1093/acrefore/9780190228637.013.717.

Nyamnjoh, F. B. 2020. Decolonising the academy: A case for convivial scholarship. Basel: Basler Afrika Bibliographien. 